Humanistika: Jurnal Keislaman

Vol. 8 No. 1 2021. ISSN (Print): 2460-5417 ISSN (Online): 2548-4400

DOI: https://doi.org/10.36835/ humanistika.v8i1.762

\title{
KONSEP ETIKA PELAJAR TERHADAP GURU \\ (Studi Komparasi Pemikiran K.H. Hasyim Asy'ari dan \\ K.H. Zainal Abidin Munawwir)
}

Fitrianingsih Wulandari

STAI Muhammadiyah Probolinggo

Fitrianingsihw.11.math@gmail.com

Devy Habibi Muhammad

STAI Muhammadiyah Probolinggo

hbbmuch@gmail.com

Ari Susandi

STAI Muhammadiyah Probolinggo

pssandi87@gmail.com

\begin{abstract}
In educational institutions, ethics is a serious problem. This is evidenced by the number of students who behave impolitely and say rudely to their teachers. So the formulation of the problem is: 1) How student ethics towards teachers according to K.H. Hashim Asy'ari and K.H. Zainal Abidin Munawwir. 2) How the similarities and differences of the thoughts of the two figures. The purpose of the study is to describe and analyze the thoughts of the two figures about the concept of student ethics towards teachers. This research uses qualitative descriptive methods and the type of research is literature research. Data collection techniques are done by collecting data obtained from library sources. While the data analysis used is content analysis. The results of the study showed that the thought of both wants that students when studying must pay attention to their ethics towards their teachers, so that their knowledge is useful. While the difference is in the number of editorials discussing the two figures and
\end{abstract}


(Studi Komparasi Pemikiran K.H. Hasyim Asy'ari dan K.H. Zainal Abidin Munawir)

differences in the background of the emergence of the thoughts of the two figures.

Keywords: Student Ethics, Teacher, K.H. Hasyim Asy'ari, K.H. Zainal Abidin Munawwir 
Fitrianingsih Wulandari

Devy Habibi Muhammad

Ari Susandi

\begin{abstract}
Abstrak
Pada lembaga pendidikan, etika menjadi suatu masalah yang cukup serius. Hal ini dibuktikan dengan masih banyaknya pelajar yang berperilaku kurang sopan serta berkata kasar terhadap gurunya. Sehingga didapatkan rumusan masalahnya yaitu: 1) Bagaimana etika pelajar terhadap guru menurut K.H. Hasyim Asy'ari dan K.H. Zainal Abidin Munawwir. 2) Bagaimana persamaan dan perbedaaan pemikiran kedua tokoh. Tujuan penelitian yaitu untuk mendeskripsikan dan menganalisis pemikiran kedua tokoh tersebut perihal konsep etika pelajar terhadap guru. Penelitian ini menggunakan metode deskriptif kualitatif dan jenis penelitiannya adalah penelitian kepustakaan. Teknik pengumpulan data dilakukan dengan mengumpulkan data-data yang didapat dari sumber kepustakaan. Sedangkan analisis data yang digunakan yaitu analisis isi. Hasil penelitian menunjukkan bahwa pemikiran keduanya sama-sama menghendaki agar pelajar ketika menuntut ilmu harus memperhatikan etikanya terhadap gurunya, agar ilmunya bermanfaat. Sedangkan perbedaannya yaitu pada banyaknya jumlah redaksi pembahasan kedua tokoh serta perbedaan latar belakang munculnya pemikiran kedua tokoh.
\end{abstract}

Kata kunci : Etika Pelajar, Guru, K.H. Hasyim Asy’ari, K.H. Zainal Abidin Munawwir. 


\section{Konsep Etika Pelajar Terhadap Guru}

(Studi Komparasi Pemikiran K.H. Hasyim Asy'ari dan K.H. Zainal Abidin Munawir)

\section{PENDAHULUAN}

Kemajuan suatu negara itu sangat tergantung pada kualitas sumber daya manusianya dan begitu juga kualitas sumber daya manusianya dikatakan baik apabila kualitas pendidikannya juga baik. Peran pendidikan sangat penting bagi terciptanya masyarakat yang religius, cemerlang, bermoral, berketerampilan, serta demokratis. ${ }^{1}$ Sebagai negara berkembang, Indonesia memandang pendidikan sebagai kebutuhan dan sarana penting untuk memajukan pembangunan nasional. Dari pengertian tersebut dapat diketahui bahwasanya pendidikan yaitu kegiatan yang ditunjukkan guna membentuk manusia yang cemerlang dalam berbagai aspek seperti intelektual, sosial, emosional, spiritual, keterampilan, berkepribadian serta dapat berperilaku yang mencerminkan akhlakul karimah yang baik. ${ }^{2}$ Adapun pengertian lain dari pendidikan adalah proses melatih perasaan siswa dengan sedemikian rupa, baik dalam bersikap, berprilaku, dan moralitas hidup ketika pengambilan keputusan yang tepat. ${ }^{3}$

Manusia merupakan makhluk yang rasional, sehingga ia dituntut untuk mempunyai suatu etika yang baik. ${ }^{4}$ Secara etimologi, etika berasal

${ }^{1}$ Anwar Yulianto, B. P. (2021). Analisis Interaksi Adab Seorang Murid Terhadap Guru Dalam Prespektif Imam Al - Ghazali. Jurnal Imtiyaz, 5(01), 30-40

2 Khosiah, N. (2019). Pelaksanaan Pendidikan Karakter Di MI Miftahul Ulum TambakRejo Tongas Probolinggo. Ar-Risalab: Media Keislaman, Pendidikan Dan Hukum Islam, 17(1), 118-128.

${ }^{3}$ Susandi, A. (2020). Pendidikan Life Skills Dalam Penanaman Nilai-Nilai Agama Islam Di Sekolah Dasar Al-Insyiroh : Jurnal Studi Keislaman, 6(2), 95-111. https://doi.org/10.35309/alinsyiroh.v6i2.3867

${ }^{4}$ Prasetiya, B. (2018). Dialektika Pendidikan Akhlak dalam Pandangan Ibnu Miskawaih dan Al-Gazālī. Intiqad: Jurnal Agama Dan Pendidikan Islam, 10(2), 249-267.

Humanistika: Vol.8 No.1 2022 


\section{Fitrianingsih Wulandari}

\section{Devy Habibi Muhammad}

\section{Ari Susandi}

dari Bahasa Yunani yakni "Ethos," yang artinya kebiasaan maupun sifatsifat moral. Etika adalah ilmu atau konsep yang dimiliki oleh perorangan ataupun masyarakat dapat menentukan apakah perilaku yang telah dilakukan ini salah atau benar serta baik ataupun buruk. ${ }^{5}$ Sedangkan secara terminologi, etika memiliki tiga pengertian yaitu Pertama, sebagai nilai dan etika yang nantinya akan menjadi pedoman bagi individu maupun kelompok untuk mengatur perilakunya. Kedua, etika berarti kumpulan asas atau nilai moral. Ketiga, etika memiliki arti ilmu tentang apa yang baik dan apa yang buruk. ${ }^{6}$ Dari pengertian tersebut, penulis dapat menyimpulkan bahwasannya etika ialah kumpulan prinsip atau nilai yang berkaitan dengan moralitas yang meliputi perilaku, perbuatan, dan watak yang perlu dimiliki oleh manusia agar dapat diterima dalam masyarakat.

Selain guru yang harus mempunyai etika profesi keguruan sudah seharusnya juga seorang pelajar mempunyai etika yang baik terhadap gurunya seperti mematuhi suatu norma ataupun aturan yang boleh untuk dikerjakan dan tidak boleh dikerjakan oleh seorang pelajar dibawah

${ }^{5}$ Abbudin Nata, ablak Tasawuf dan kararkter mulia (Jakarta: PT Raja Grafindo Persada, 2014 ), h.75

${ }^{6}$ Baraja, A., Ridlo, A. A., Ali, N., \& Khamid, A. (2020). Konsep Etika Pelajar (Studi Komparasi Kh. Hasyim Asy'ari dan Umar bin Ahmad Baraja). Jurnal Pendidikan Islam Al-Affan, 1(1), 1-13. 


\section{Konsep Etika Pelajar Terhadap Guru}

(Studi Komparasi Pemikiran K.H. Hasyim Asy'ari dan K.H. Zainal Abidin Munawir)

pengawasan serta pengarahan oleh seorang pendidik dalam proses pembelajaran. ${ }^{7}$

Namun hingga saat ini masih banyak ditemukan fenomena terkait etika anak didik terhadap gurunya seperti halnya kurangnya sopan santun, berkata kasar dan masih banyak lagi fenomena yang lain. Hal ini sangat disayangkan padahal sudah sepatutnya seorang guru harusnya di hormati dan dimuliakan, sebab berkahnya ilmu tergantung pada ridhonya guru.

Menurut penulis, fenomena di atas terjadi karena kurangnya pemahaman dan implementasi terhadap etika pelajar di era sekarang ini. Untuk mengatasi fenomena di atas, perlu pembahasan dan pengkajian kembali tentang konsep etika peserta didik terhadap pendidik melaui pemikiran Kyai Hasyim Asy ari dan Zainal Abidin Munawir. Selain itu juga dibutuhkan pendidik yang mampu memotivasi pelajar agar dapat menanamkan nilai-nilai akhlak dan etika di sekolah maupun di luar sekolah. Karena tidak dapat dipungkiri bahwa etika pelajar sangat penting untuk kesuksesan masa depan dan kemaslahatan serta berkahnya ilmu, sebab guru adalah orang dewasa yang mempunyai tanggung jawab untuk membimbing maupun memberikan bantuan bagi perkembangan fisik dan mental pelajar dalam rangka mencapai kedewasaan dan untuk dapat

\footnotetext{
${ }^{7}$ Ikhsanuddin, M., \& Amrulloh, A. (2019). Etika Guru dan Murid Perspektif KH. Hasyim Asy'ari dan Undang-

Undang Guru dan Dosen. Jurnal Pendidikan Islam, 3(2), 193-194.
}

Humanistika: Vol.8 No.1 2022 


\section{Fitrianingsih Wulandari}

\section{Devy Habibi Muhammad}

\section{Ari Susandi}

melaksanakan tugasnya di dunia sebagai ciptaan Allah SWT. ${ }^{8}$ Menurut Islam, pendidik bukan hanya pembimbing, tetapi juga sosok teladan akhlak yang baik dan hal ini tidak serta merta terdapat pada pembimbing. Dimana menurut Kyai Hasyim seorang guru dalam mengajar haruslah memiliki ciri-ciri berikut : dapat melindungi diri dari segala sesuatu yang dapat merendahkan martabatnya, harus pandai mengajar, berpikiran terbuka, dapat mengamalkan ajaran dalam Al-Qur'an dan Hadits, profesional, berwibawa, serta selalu bertaqwa kepada Allah SWT, tawadhu', zuhud dan khusyu. ${ }^{10}$

Studi kompasi pemikiran dari kedua tokoh ini dilatar belakangi karena kedua tokoh ini adalah tokoh ulama Indonesia yang hidup pada era yang berbeda, dimana Kyai Hasyim Asy'ari adalah salah satu tokoh nasionalis yang hidup pada era perjuangan kemerdekaan Indonesia dan Kyai Zainal Abidin Munawwir adalah seorang tokoh ulama terkemuka yang hidup di masa reformasi dari latar belakang yang berbeda inilah kemudian dapat membuahkan dua hasil pemikiran mengenai etika peserta didik terhadap guru.

${ }^{8}$ Hidayah, U. (2018). Rekontruksi Evaluasi Pendidikan Moral Menuju Harmoni Sosial. Jurnal Pedagogik, 05(01), 69-81.

${ }^{9}$ Ikhsanuddin, M., \& Amrulloh, A. (2019). Etika Guru dan Murid Perspektif KH. Hasyim Asy'ari dan Undang- Undang Guru dan Dosen. Jurnal Pendidikan Islam, 3(2), 193194.

10 Martono. (2020). Pemikiran Pendidikan Islam KH . Hasyim Asy' ari ( Perspektif Epistimologi Sosial Keagamaan Dan Konsep Pendidikan Islam Bagi Guru Dan Peserta Didik ). Jurnal Pendidikan Islam, 6(1), 40-45. 


\section{Konsep Etika Pelajar Terhadap Guru}

(Studi Komparasi Pemikiran K.H. Hasyim Asy'ari dan K.H. Zainal Abidin Munawir)

Adapun rumusan masalahnya, yaitu: 1) Bagaimana etika pelajar terhadap guru menurut pemikiran K.H. Hasyim Asy'ari dan K.H. Zainal Abidin Munawwir dan 2) Bagaimana persamaan dan perbedaan pemikiran terkait konsep etika pelajar terhadap guru dari kedua tokoh tersebut. Adapun tujuan dari penelitian ini yaitu untuk mendeskripsikan dan menganalisis etika siswa terhadap guru berdasarkan pemikiran K.H. Hasyim Asy'ari dan K.H. Zainal Abidin Munawwir.

Berdasarkan uraian latar belakang masalah diatas, peneliti tertarik untuk mengkaji pemikiran KH. Hasyim Asy'ari dan K.H. Zainal Abidin Munawwir mengenai etika seorang pelajar terhadap guru dalam penelitian kepustakaan dengan judul sebagai berikut " Konsep Etika Pelajar Terhadap Guru ( Studi Komparasi Pemikiran K.H Hasyim Asy'ari K.H. Zainal Abidin Munawwir)”

\section{METODE PENELITIAN}

Penelitian yang digunakan dalam artikel ini adalah metode deskriptif kualitatif dengan menggunakan jenis penelitian kepustakaan (Library Research) yaitu dengan cara mengulas buku atau data tertulis yang berkesinambungan dengan penulisan jurnal ini. ${ }^{11}$ Dalam hal ini, peneliti menganalisis beberapa data yang relevan dengan judul yang tengah dibahas.

Teknik pengumpulan data dalam penelitian ini, diperoleh melalui dua sumber, sumber tersebut yaitu : Pertama, sumber data primer. Data utama

\footnotetext{
${ }^{11}$ Zed. M (2018), Metode penelitian kepustakaan. Jakarta : Yayasan Obor.
}

Humanistika: Vol.8 No.1 2022 
Fitrianingsih Wulandari

Devy Habibi Muhammad

Ari Susandi

ini meliputi bahan-bahan yang berhubungan secara langsung dengan objek penelitian, yaitu dokumen dari kedua tokoh tersebut. Kedua, sumber data sekunder. Data sekunder diperoleh peneliti dengan cara mengidentifikasikan karya-karya lain yang relevan dengan penelitian ini, seperti halnya yang ada di jurnal, web (internet), artikel dan sebagainya. ${ }^{12}$

Teknik analisis data yang digunakan oleh penulis dalam penelitian ini adalah analisis isi (content analysis). Analisis isi ini digunakan untuk membandingkan satu pemikiran dengan pemikiran yang lain sesuai dengan artikel ini. ${ }^{13}$

\section{HASIL DAN PEMBAHASAN}

Etika Pelajar Terhadap Guru Menurut KH. Hasyim Asy’ari dan KH. Zainal Abidin Munawir

\section{Konsep Etika Pelajar Terhadap Guru Menurut K.H. Hasyim Asy’ari}

Nama lengkap K.H. Hasyim Asy'ari adalah Hasyim Asy'ari bin Abdul Wahid bin Abdul Halim bin Abdurrahman Bin Sultan Hadi Wijaya bin Abdullah bin Abdul Aziz bin Abdul Fatah bin Maulana Ishaq. Beliau merupakan anak ke-3 dari pasangan Kyai Asy'ari dangan Ny. Halimah. Ia lahir pada hari selasa 14 Februari $1871 \mathrm{M}$ atau 24 Dzulqa'idah $1287 \mathrm{H}$ di

12 Arikunto, Suharsimi. Prosedur Penelitian: Suatu Pendekatan Praktik. Jakarta: PT Rineka Cipta. 2010

${ }^{13}$ Muhammad, D. H., \& Deasari, A. E. K. A. (2021). Pendidikan Anak Usia Dini Berbasis Psikologi Islam. Jurnal Pendidikan Islam Al- Ilmi, 4(1), 21-33. 


\section{Konsep Etika Pelajar Terhadap Guru}

(Studi Komparasi Pemikiran K.H. Hasyim Asy'ari dan K.H. Zainal Abidin Munawir)

Desa Gedang Jombang, Jawa Timur dan pada tanggal 21 Juli 1947 atau 7 Ramadhan $1366 \mathrm{H}$ beliau wafat. Disamping itu, beliau merupakan seorang pahlawan nasional Indonesia serta pendiri Nahdatul Ulama (NU). ${ }^{14}$ Adapun karyanya cukup banyak salah satu karya dari beliau yaitu kitab Adab al-'Alim wa al-Muta'allim. Kitab tersebut terdapat delapan bab. Namun untuk fokus pembahasannya terdapat pada bagian ketiga yakni membahas tentang etika peserta didik terhadap guru. Etika yang seharusnya dimiliki oleh pelajar terhadap guru Menurut K.H. Hasyim As'yari dalam kitabnya, yakni Adab al-'Alim wa al-Muta'allim yaitu ada 12 poin, antara lain yaitu : ${ }^{15}$

a. Seorang pelajar, dalam memilih figur seorang guru hendaknya berdoa terlebih dahulu dan tidak lupa meminta petunjuk kepada Allah swt. Hal ini dilakukan untuk kita agar dimudahkan oleh Allah dalam menemukan sosok pengajar yang mampu untuk dijadikan seorang pengajar dalam menuntut ilmu serta mampu memberikan pengarahan kepada kita untuk menjadi orang yang lebih baik lagi daripada sebelumnya, salah satunya seperti halnya mengenai akhlak.

b. Carilah guru dengan sungguh-sungguh dan percaya bahwa pendalaman ilmu agamanya akan diakui oleh guru lain. Hal ini dapat membuktikan bahwa ilmu tersebut diyakini kebenarannya dan jangan menuntut ilmu dengan guru yang hanya mengambil ilmu dari buku

\footnotetext{
${ }^{14}$ KH. Hasyim Asy'ari, Etika pendidikan islam, terj Mohammad Kholil ( Yogyakarta : titian wacana 2007),

15 Asy'ari, tt : 29-43
}

Humanistika: Vol.8 No.1 2022 


\section{Fitrianingsih Wulandari}

\section{Devy Habibi Muhammad}

Ari Susandi

saja tanpa belajar secara langsung, karena hal tersebut akan membuat kita menerima ilmu yang terbatas.

c. Pelajar harus patuh apapun perintah yang diberikan guru kepadanya dan menjahui segala larangan, agar ilmunya dapat barakah.

d. Memandang guru sebagai orang yang mulia. K.H. Hasyim Asy'ari menuturkan, bahwa pelajar hendaklah memandang seorang guru sebagai orang yang mulia dan sudah sepatutnya untuk memuliakannya, sebab guru merupakan sosok orang yang telah banyak berjasa dalam hidup kita setelah orang tua kita.

e. Memperhatikan sesuatu yang menjadi hak seorang guru. Kyai Hasyim Asy'ari menuturkan, bahwa seoarang pelajar hendaknya memperhatikan sesuatu hak yang menjadi hak guru, sebab apabila kita melupakan hak-hak guru. Maka hal itu akan menyebabkan hilangnya keberkahan ilmu yang didapatkan.

f. Bersabar jika perilakunya kurang menyenangkan. Jangan beranggapan bahwa itu kesalahan. Tetaplah hormat padanya. Seperti halnya penuturan beliau, bahwa seorang murid hendaknya bersabar atas kerasnya sikap guru. Sikap buruk guru tidak boleh membuat pelajar memandang rendah guru, atau meragukan kesempurnaan pengetahuan dan keterampilannya atau bahkan tidak mau belajar atau membenci guru. Sebab semua yang dilakukan guru dilihat dari sisi positifnya saja dan yakinlah bahwa itu merupakan suatu bentuk 


\section{Konsep Etika Pelajar Terhadap Guru}

(Studi Komparasi Pemikiran K.H. Hasyim Asy'ari dan K.H. Zainal Abidin Munawir)

kenikmatmatan yang Allah Swt berikan dalam bentuk pengawasan maupun perhatian guru kepada pelajar. Pelajar harus berterima kasih kepada guru atas tegurannya, dan percaya bahwa setiap teguran memiliki bimbingan dan kebaikan dunia dan dunia.

g. Meminta izin dengan mengetuk pintu sebanyak 3 kali setiap mau memasuki ruangan guru dan tidak mengetuk pintu dengan ketukan yang keras. Kyai Hasyim Asy'ari menuturkan, bahwa seorang pelajar ketika hendak memasuki ruangan pribadi seorang guru, maka yang harus dilakukan oleh pelajar yaitu mengetuk pintu maksimal 3 kali dan tidak dengan ketukan yang keras. Apabila guru mengizinkan, maka masuklah dengan sopan dan jika tidak di izinkan, maka tinggalkanlah tempat tersebut dengan sopan.

h. Hendaklah pelajar duduk dengan sopan dan santun ketika bersama pendidik. Kyai Hasyim Asy'ari menuturkan, kita sebagai pelajar sudah sepatutnya ketika bersama guru hendaklah untuk duduk dengan sopan dan santun yaitu dengan duduk yang baik.

i. Bicaralah yang sopan dan lembut kepada seorang guru. Kyai Hasyim Asy'ari menerangkan, bahwasannya seorang siswa ketika saat berbicara dengan seorang guru hendaklah berbicara dengan sopan santu dengan suara yang lemah lembut dan jangan berbicara dengan kasar yang terhadap guru, karena hal itu dapat menyakiti perasaannya. 


\section{Fitrianingsih Wulandari}

\section{Devy Habibi Muhammad}

\section{Ari Susandi}

j. Ketika materi yang dijelaskan sudah diketahui sebelumnya, maka lanjutkan mendengarkan seolah-olah kita belum pernah mendengarnya. Kemudian, jika pelajar diminta menjelaskan suatu hal, meskipun sebenarnya mampu. Maka ia mengatakan bahwa saya lebih suka mendengar penjelasan dari guru secara langsung. K.H. Hasyim Asy'ari menuturkan, bahwasanya ketika guru menyampaikan materi pembelajaran dan ternyata materi tersebut merupakan materi yang sudah diketahui pelajar sebelumnya, maka sikap pelajar seharusnya mendengarkan dengan baik penjelasan guru tanpa menampakkan bahwa pelajar sudah mengetahui materi tersebut sebelumnya

pelajar harus menganggap bahwa pengetahuan yang diberikan kepadanya oleh guru adalah pengetahuan baru, yang belum pernah didengar, dan belum pernah dipelajari. Jika guru menanyakan suatu terkait materi dan ternyata materi itu sudah diketahui dan pelajar mampu menjelaskannya, maka pelajar jangan menjawab "ia" sebab hal tersebut seakan-akan menunjukkan bahwa pelajar sudah tidak lagi memerlukan guru untuk menjelaskannya. Tetapi, jika dijawab tidak, maka pelajar akan berbohong. Maka jawaban terbaiknya adalah "saya merasa lebih senang mendengarkan penjelasan tersebut langsung dari Ibu atau Bapak guru", sehingga pelajar tidak pamer 


\section{Konsep Etika Pelajar Terhadap Guru}

(Studi Komparasi Pemikiran K.H. Hasyim Asy'ari dan K.H. Zainal Abidin Munawir)

terhadap ilmu yang dimilikinya dan juga tidak berbohong bahwa ilmu yang diajarkan sudah diketahuinya sebelumnya.

k. Tidak mendahului penjelasan guru dengan maksud pamer. Kyai Hasyim Asy’ari menuturkan, bahwa di dalam suatu majelis, pelajar harus diam mendengarkan penjelasan sang guru. Jika tidak memahami suatu materi maka bertanyalah dengan guru terkait materi yang belum dimengerti. Jika ingin bertanya maka tunggulah sampai giliran tiba, jangan memotong penjelasan guru, apalagi menjawab pertanyaan pelajar lain dengan niat untuk pamer. Jika guru sedang menjelaskan, jangan pula pelajar mengobrol dengan yang lain dan tidak memperhatikan penjelasan yang diberikan guru, dan jangan menganggap bahwa pertanyaan itu tidak bermanfaat untuknya atau tidak ada hubungannya dengan pertanyaan yang akan ia tanyakan nanti. Semua peserta majelis harus menjaga ketertiban dan selalu fokus pada materi yang dijelaskan oleh guru. Kemudian, ketika guru menyuruhnya melakukan sesuatu tanpa mengulangi perintah yang dikomunikasikan sebelumnya, siswa juga harus merespon.

1. Jika seorang siswa diminta untuk membaca buku, ia harus menerimanya dengan tangan kanannya dan memegangnya dengan kedua tangan. K.H. Hasyim Asy'ari menuturkan, bahwasannya seorang pelajar ketika diminta oleh seorang guru untuk membacakan suatu kitab, maka hendaklah ia menerimanya dengan tangan yang baik yakni tangan kanan dan juga dapat memegangnya dengan kedua 
Fitrianingsih Wulandari

Devy Habibi Muhammad

Ari Susandi

tangannya. Hal ini merupakan bentuk etika yang baik dari seorang pelajar terhadap gurunya. ${ }^{16}$

Demi mendekatkan diri kepada Allah SWT dan menerima ridho dari guru, etika diatas harus diterapkan. Sebab keberkahan ilmu pada seorang pelajar itu terletak pada gurunya. Oleh karena itu, sebagai kita harus dan hormat terhadap guru baik dalam segala perilaku dan perbuatan kita pada saat sedang belajar atau tidak sedang belajar.

\section{Konsep Etika Pelajar Terhadap Guru Menurut K.H. Zainal}

\section{Abidin Munawwir}

K.H Zainal Abidin Munawwir bin KH. Muhammad Munawwir bin K.H. Abdullah Rosyad bin K.H. Hasan Bashori atau biasa disapa Mbah Zainal. Beliau lahir pada tanggal 31 Oktober 1931 M yang bertepatan dengan 18 Jumadil Akhir 1350 H di Bantul, Yogyakarta, sedangkan pada tanggal 15 Februari 2014 beliau wafat dan dimakamkan dipemakaman di kampung Sorowajan, Pendukuhan Glugo, Desa Panggungharjo, Kecamatan Sewon, Kabupaten Bantul. Beliau merupakan putra ke 9 dari pasangan K.H Munawwir dengan Ny. Hj. Khodijah (Sukistiyah). Selain itu, beliau terkenal sebagai seorang tokoh ulama yang ahli dalam ilmu Qiraat Al-Qur'an, sehingga ia diberi julukan sebagai ulama ahli fiqihnya daerah Yogyakarta di masa sekarang ini. Beliau juga salah seorang pengasuh

${ }^{16}$ Bagaskara, R. (2019). Reorientasi Pemikiran Pendidikan KH.M.Hasyim Asy'ari : Etika dalam Pendidikan Islam. Jurnal Studi Islam, 6(2), 153-168. 


\section{Konsep Etika Pelajar Terhadap Guru}

(Studi Komparasi Pemikiran K.H. Hasyim Asy'ari dan K.H. Zainal Abidin Munawir)

pendiri pondok pesantren Al-Munawwir Krapyak. ${ }^{17}$ Adapun karyanya cukup banyak salah satu karya dari Mbah Zainal yaitu kitab Wazaif alMuta'allim. Dimana kitab ini menjelaskan mengenai pendidikan karakter yang meliputi etika peserta didik dan pendidik. ${ }^{18}$

Karena kegelisahan yang pada saat itu tengah dirasakan oleh beliau tentang pendidikan yang ada di Indonesia, tepatnya pada masa reformasi yang menyimpang dari tujuan pendidikan, yang mana pada saat itu terjadi pembagian atas dua kelompok yang saling bertentangan, dimana ada yang menganggap bahwa ilmu dunia lebih penting daripada ilmu agama. Alasanya ilmu dunia akan dapat membawa kesuksesan dalam kehidupan didunia. Sehingga ilmu umum lebih penting jika dibandingkan dengan ilmu agama. Adanya kejadian tersebut sangat memprihatinkan, sebab dengan kejadian itu nantinya dapat membuat ilmu pelajar bisa terancam di kemudian hari, yakni hilang jati diri pelajar yang sebenarnya. Maka dari itu beliau mempertegas bahwa pada saat mencari ilmu, kita tidak boleh membeda-bedakan antara ilmu agama dan ilmu umum, sebab keduanya tersebut memiliki kaitan yang erat baik kedudukan, kegunaannya serta tujuan keduanya yaitu sama-sama untuk mengapai ketaqwaaan kepada Allah Swt. Namun, dari kedua ilmu tersebut ilmu agama tetap menjadi dasar yang utama dalam diri pelajar guna untuk beribadah.Oleh sebab itu, untuk mengatasi keresahan yang terjadi pada saat itu dan pada masa yang

\footnotetext{
${ }^{17}$ Djunaidi A, Op.Cit, hal. 60-61.

18 Zainal Abidin Munawwir, Op.Cit, hal.4

Humanistika: Vol.8 No.1 2022
} 


\section{Fitrianingsih Wulandari}

\section{Devy Habibi Muhammad}

\section{Ari Susandi}

akan datang, beliau kemudian memberikan jalan keluar agar dapat memperkecil munculnya terjadinya suatu bahaya atas pembagian pendapat antara ke dua ilmu yakni ilmu agama dan ilmu umum. Salah satu caranya dengan memberitahukan serta mengingatkan bahwasanya seorang murid haruslah selalu memperhatikan adabnya kepada gurunya. Hal ini dilakukan untuk mencegah terjadinya penurunan moralitas seorang pelajar kepada seorang pendidik.

Pelajar dalam mencari ilmu haruslah wajib mempunyai etika yang baik terhadap seorang guru, sebab beliau merupakan orang yang memiliki ilmu yang nantinya memberi ilmunya kepada kita, sehingga kita harus patuh serta menghormati segala perintahnya selagi itu masih dalam hal kebaikan. Menurut K.H. Zainal Abidin Munawwir, dalam kitab Wazaif AlMuta'allim tepatnya pada bagian ketiga yakni adab Al-Muta'allim Ma'a Ustazi menguraikan bahwa etika yang harus di miliki oleh seorang murid terhadap guru terdiri dari 7 poin, yaitu sebagai berikut :

a. Meminta izin ketika ingin belajar, Mbah Zainal menuturkan bahwasanya seorang murid ketika ingin mengikuti kegiatan pembelajaran hendaknya izin terlebih dahulu kepada seorang guru, sebab hal ini bertujuan agar tertib dalam menuntut ilmu tidak asal mengikuti pembelajaran saja.

b. Meminta izin ketika tidak masuk atau ingin keluar dari sekolah, Mbah Zainal menuturkan, adab yang kedua yaitu setelah proses 


\section{Konsep Etika Pelajar Terhadap Guru}

(Studi Komparasi Pemikiran K.H. Hasyim Asy'ari dan K.H. Zainal Abidin Munawir)

pembelajaran selesai ataupun ingin keluar dari majlis ilmu tersebut, maka seorang murid hendaknya meminta izin untuk berpamitan serta meminta do’a kepada gurunya agar mendaptkan kemanfaatan maupun keberkahan ilmunya.

c. Etika bersosialisasi dan bergaul dengan guru. Mbab Zainal menuturkan bahwasanya murid harus sabar ketika ingin menemui gurunya dengan cara mencari waktu senggangnya. Maka, seorang murid harus memanfaatkan kesempatan waktunya dengan sebaik mungkin, seperti halnya kesempatan untuk menanyakan sesuatu hal mengenai persoalan yang belum dipahaminya dengan tetap bersikap sopan santun.

d. Seorang pelajar di sunnahkan berdiri untuk menghormati dan mencium tangan seorang pendidik. Mbah Zainal menuturkan, seorang pelajar diperbolehkan berdiri untuk menghormati seorang pendidik serta mencium tangannya, merangkul karena itu merupakan salah satu bentuk menghormati seorang guru.

e. Seorang murid hendaknya memuliakan seorang guru salah satunya dengan memberikan hak upah dalam mengajar. Seorang guru diperbolehkan menerima upah sebagai pengajar, mengenai hal ini jangan dijadikan alasan bagi seorang murid untuk tidak lagi menghormati guru dan lantas guru di anggapnya sebagai teman. Jika hal tersebut sampai dilakukan oleh murid, maka hal tersebut telah 
Fitrianingsih Wulandari

Devy Habibi Muhammad

Ari Susandi

merendahkan eksistensi dari seorang guru dan bersikap tercela kepadanya.

f. Membantu guru dalam kebenaran dengan memperkuat unsur pendidikan dan pengajaran. Seorang siswa dapat membantu gurunya dengan berusaha mengatur keperluan dalam kegiatan pembelajaran seperti membantu guru untuk mengatur teman-teman dikelas agar tertib dalam mengikuti proses kegiatan pembelajaran, membantu untuk menyiapkan sarana dan prasarana dalam pembelajaran. Hal ini termasuk pemurnian agama.

g. Menyerahkan segala urusan keilmuan kepada ahlinya yakni pada seorang pendidik, apabila pendidik sedang menasehati peserta didik serta sedang mengarahkan maka sebaiknya peserta didik harus pasrah tidak boleh membantah. ${ }^{19}$

\section{Hasil Analisis Komparasi Konsep Etika Pelajar Terhadap Guru} Menurut K.H. Hasyim Asy'ari dan K.H. Zainal Abidin Munawwir.

Adapun hasil analisis penelitian mengenai pemikiran dari kedua tokoh yakni Kyai Hasyim Asy ari dan Kyai Zainal Abidin Munawwir mengenai konsep etika pelajar terhadap guru. Dapat diperoleh persamaan dan

${ }^{19}$ Sugiarto, A. B. (2019). Adab Peserta Didik Terhadap Pendidik Prespektif KH. Zainal Abidin Munawwir dan Relevansinya Dengan Pendidikan Islam (Tela ah Kitab Wazhaif al-Muta'allim). 
perbedaan antara pemikiran keduannya. Untuk lebih jelasnya, maka penulis akan memaparkan dalam bentuk tabel, yaitu sebagai berikut :

Tabel 1. Komparasi Etika pelajar terhadap guru Menurut KH. Hasyim Asy’ari dan KH. Zainal Abidin Munawwir

\begin{tabular}{|c|c|c|c|}
\hline No & Aspek & Persamaan & Perbedaan \\
\hline 1. & $\begin{array}{c}\text { Etika } \\
\text { pelajar } \\
\text { kepada } \\
\text { seorang } \\
\text { guru }\end{array}$ & $\begin{array}{l}\text { Persamaan antara kedua } \\
\text { tokoh tersebut mengenai } \\
\text { etika pada peserta didik } \\
\text { kepada guru yaitu } \\
\text { keduanya menghendaki } \\
\text { agar seorang peserta didik } \\
\text { ketika menuntut ilmu } \\
\text { perlu memperhatikan } \\
\text { etika terhadap gurunya, } \\
\text { agar ilmu yang } \\
\text { diperolehnya dari guru } \\
\text { dapat bermanfaat dan } \\
\text { barokah. }\end{array}$ & 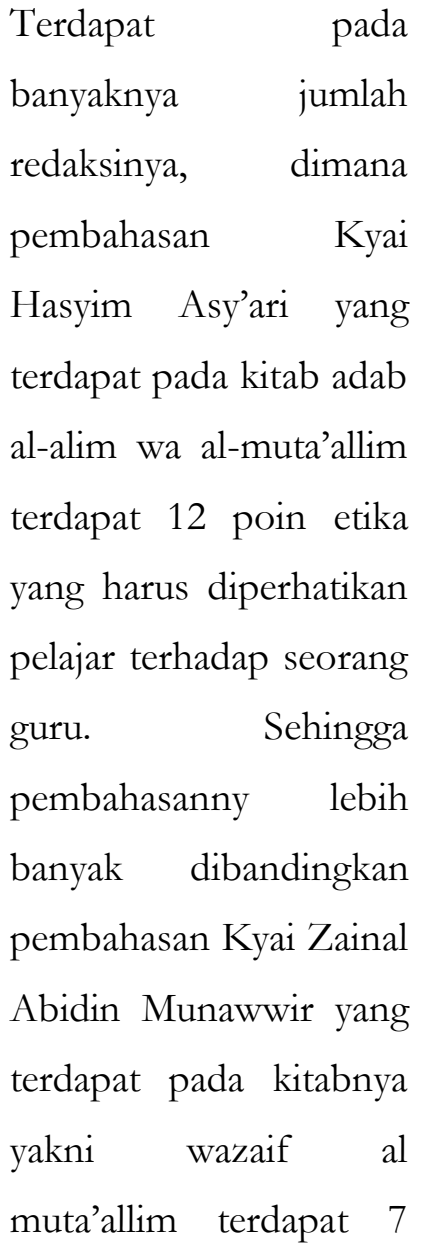 \\
\hline
\end{tabular}

Humanistika: Vol.8 No.1 2022 


\begin{tabular}{|c|c|c|c|}
\hline & & & $\begin{array}{l}\text { poin mengenai etika } \\
\text { yang harus diperhatikan } \\
\text { oleh murid kepada } \\
\text { gurunya. }\end{array}$ \\
\hline 2. & $\begin{array}{c}\text { Latar } \\
\text { belakang } \\
\text { munculnya } \\
\text { pemikiran } \\
\text { kedua } \\
\text { tokoh }\end{array}$ & $\begin{array}{l}\text { Pemikiran tersebut dilatar } \\
\text { belakangi adanya bentuk } \\
\text { perhatian serta kepedulian } \\
\text { antara kedua tokoh ulama } \\
\text { Indonesia yang berbeda } \\
\text { era yaitu K.H Hasyim } \\
\text { Asy'ari dengan K.H. } \\
\text { Zainal Abidin Munawwir } \\
\text { mengenai perkembangan } \\
\text { umat manusia yang lebih } \\
\text { baik lagi khususnya } \\
\text { mengenai masalah etika } \\
\text { pelajar akan seorang guru } \\
\text { yang mengalami } \\
\text { kemerosotan serta } \\
\text { memprihatinkan }\end{array}$ & $\begin{array}{l}\text { a. Kyai Hasyim Asy'ari } \\
\text { merupakan salah } \\
\text { satu tokoh } \\
\text { nasionalis } \quad \text { serta } \\
\text { pendiri } \quad \text { Nahdatul } \\
\text { Ulama (NU) yang } \\
\text { hidup pada era } \\
\text { perjuangan } \\
\text { kemerdekaan } \\
\text { Indonesia, dimana } \\
\text { pada masa itu etika } \\
\text { pelajar terhadap } \\
\text { murid sangat } \\
\text { memprihatinkan, } \\
\text { sehingga hal inilah } \\
\text { yang akhirnya } \\
\text { melatarbelakangi } \\
\text { munculnya }\end{array}$ \\
\hline
\end{tabular}




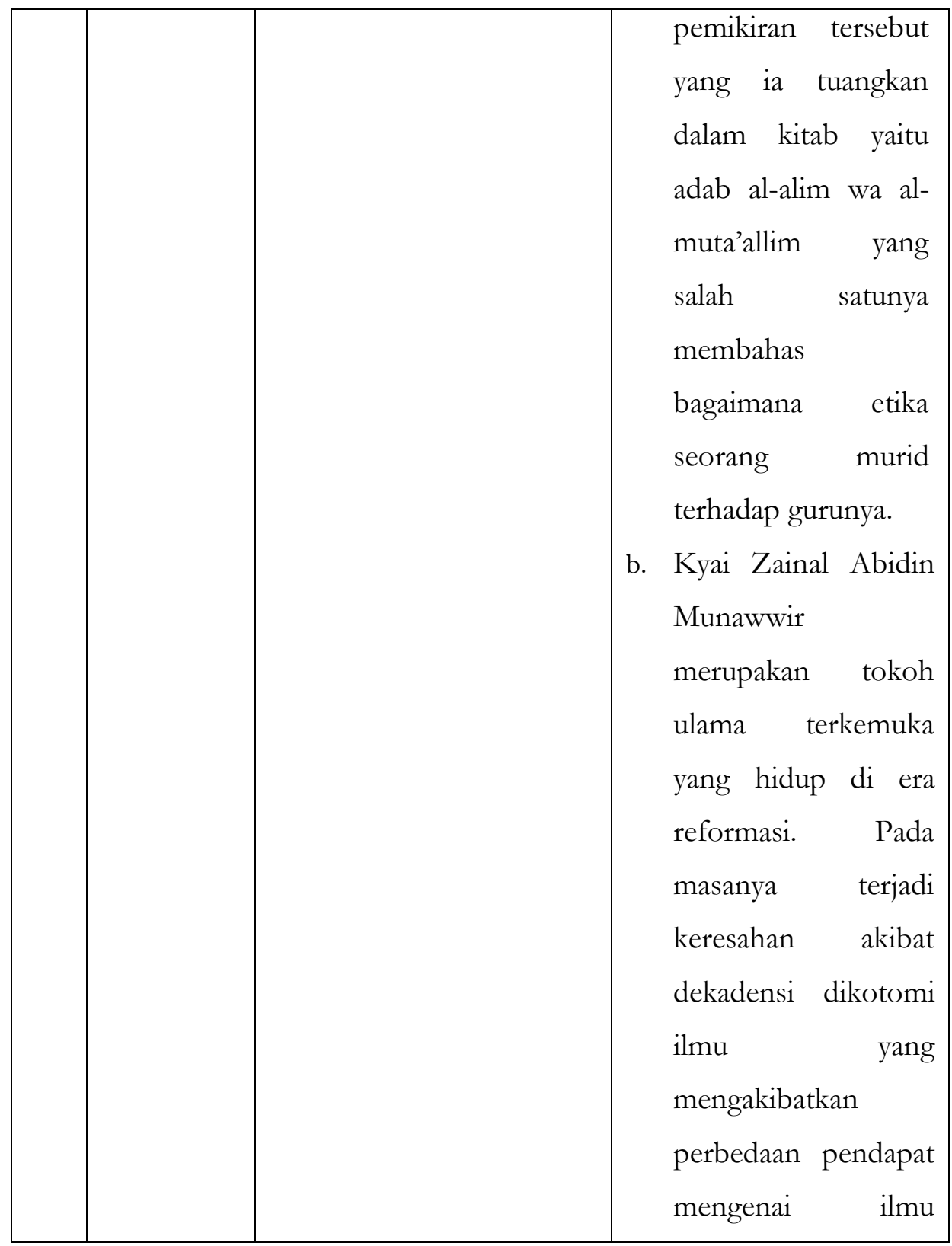

Humanistika: Vol.8 No.1 2022 


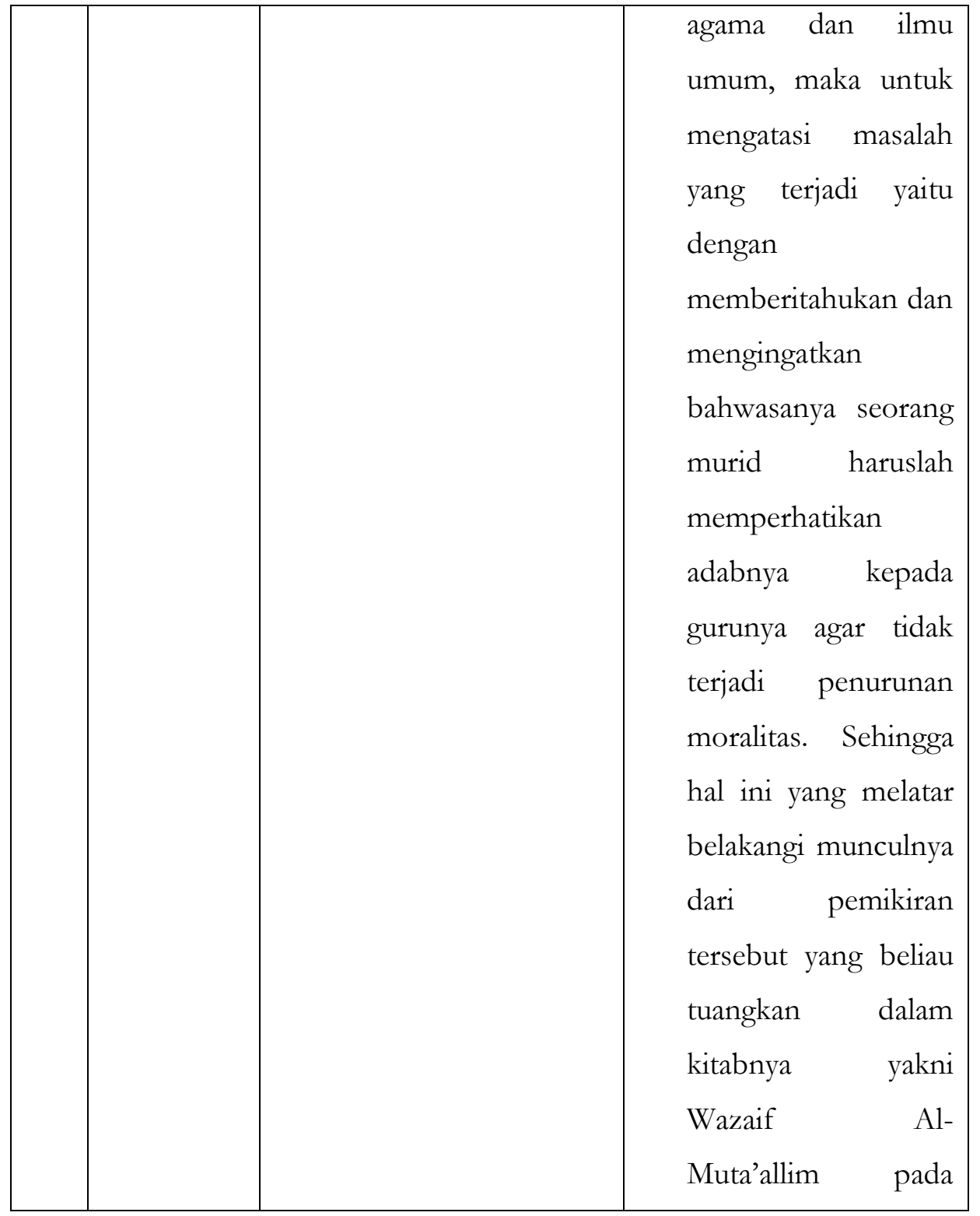




\begin{tabular}{|l|l|l|}
\hline & & $\begin{array}{l}\text { bagian ketiga yakni } \\
\text { adab Al-Muta'allim } \\
\text { Ma'a Ustazi. }\end{array}$ \\
\hline
\end{tabular}

Berdasarkan data tabel diatas sudah terlihat jelas mengenai persamaan serta perbedaan dari pemikiran kedua tokoh tersebut. Persamaan antara kedua tokoh mengenai etika pelajar kepada guru yaitu keduanya menghendaki agar seorang murid saat menuntut ilmu perlu memperhatikan etikanya terhadap gurunya, agar ilmu yang diperolehnya dapat bermanfaat dan barokah serta pemikiran keduanya sama-sama dilatar belakangi adanya bentuk perhatiaan dan kepedulian mengenai perkembangan umat manusia yang lebih baik khususnya pada masalah etika pelajar kepada guru yang mengalami kemerosotan dan keprihatinan. Perbedaannya yaitu terdapat pada banyaknya jumlah redaksinya. Selain itu Kyai Hasyim yang hidup di masa perjuangan kemerdekaan Indonesia, dimana pada masa itu etika pelajar terhadap guru sangat memprihatinkan, dengan begitu akhirnya muncullah pemikiran yang kemudian di tuangkan dalam kitabnya yaitu adab al-alim wa al-muta'allim yang salah satunya membahas bagaimana etika seorang murid terhadap gurunya. Sementara Kyai Zainal yang hidup di era reformasi, dimana pada masa itu terjadi keresahan akibat dekadensi dikotomi ilmu yang mengakibatkan perbedaan pendapat mengenai ilmu agama dan ilmu umum, maka untuk mengatasi masalah tersebut yaitu dengan memberitahukan dan mengingatkan bahwasanya seorang murid haruslah memperhatikan adabnya kepada 


\section{Fitrianingsih Wulandari}

\section{Devy Habibi Muhammad}

Ari Susandi

gurunya agar tidak terjadi penurunan moralitas. Sehingga muncullah pemikiran tersebut yang beliau tuangkan dalam kitabnya yakni Wazaif AlMuta'allim pada bagian ketiga yakni adab Al-Muta'allim Ma'a Ustazi.

\section{Kesimpulan}

Berdasarkan penelitian yang penulis lakukan mengenai konsep etika seorang pelajar kepada guru dengan mengkomparasikan pemikiran kedua tokoh tersebut, maka penulis dapat menarik kesimpulan, yaitu

1. Menurut K.H. Hasyim As'yari dalam kitabnya, yakni Adab al-'Alim wa al-Muta'allim, etika yang seharusnya dimiliki oleh pelajar terhadap guru yaitu ada 12 poin. Sedangkan Menurut K.H. Zainal Abidin Munawwir, dalam kitab Wazaif Al-Muta'allim tepatnya pada bagian ketiga yakni adab Al-Muta'allim Ma'a Ustazi menguraikan bahwa etika yang harus di miliki oleh seorang murid terhadap guru terdiri dari 7 poin.

2. Persamaan antara kedua tokoh mengenai etika pada peserta didik kepada guru yaitu keduanya menghendaki agar seorang murid saat menuntut ilmu perlu memperhatikan etikanya terhadap gurunya, agar ilmu dapat bermanfaat dan barokah serta pemikiran keduanya samasama dilatar belakangi adanya bentuk perhatiaan dan kepedulian mengenai perkembangan umat manusia yang lebih baik khususnya pada masalah etika pelajar kepada guru agar tidak mengalami kemerosotan moralitas pada peserta didik. Perbedaannya yaitu terdapat pada banyaknya jumlah redaksinya, dimana pembahasan mengenai 


\section{Konsep Etika Pelajar Terhadap Guru}

(Studi Komparasi Pemikiran K.H. Hasyim Asy'ari dan K.H. Zainal Abidin Munawir)

etika pelajar terhadap guru menurut Kyai Hasyim Asy’ari lebih banyak dibandingkan Kyai Zainal Abidin. Selain itu dari perbedaan latar belakang munculnya pemikiran antara kedua tokoh yang hidup di era perjuangan kemerdekaan Indonesia dan hidup di era reformasi dengan masalah yang terjadi pada saat itu akhirnya kemudian dapat membuahkan dua hasil pemikiran yang berbeda mengenai etika peserta didik terhadap guru yang dapat digunakan sebagai rujukan dalam mengatasi kemerosotan moralitas pelajar.

\section{DAFTAR PUSTAKA}

Asy ári, M. Hasyim. tt. Etika Pendidikan Islam: Petuah KH. M. Hāsyim Asy ari untuk para Guru (Kiai) dan Murid (Santri), terjemah dari kitab Adab al-'Alim wa al-Muta'allim. Terjemahan oleh Mohamad Kholil. Yogyakarta: Titian Wacana. 2007.

Asy ‘ri, M. Hasyim. tt. Pendidikan Akhlak untuk Pengajar dan Pelajar, terjemah dari kitab Adāb al-'Ālim wa al-Muta'allim. Terjemahan oleh Tim Dosen Ma’had Aly Hasyim Asy'ari. Tebuireng. Pustaka Tebuireng. 2018.

Arikunto, Suharsimi. Prosedur Penelitian: Suatu Pendekatan Praktik. Jakarta: PT Rineka Cipta.

2010

Anwar Yulianto, B. P. (2021). Analisis Interaksi Adab Seorang Murid Terhadap Guru Dalam Prespektif Imam Al - Ghazali. Jurnal Imtiyaz, 5(01), 30-40 
Fitrianingsih Wulandari

Devy Habibi Muhammad

Ari Susandi

Bagaskara, R. (2019). Reorientasi Pemikiran Pendidikan KH.M.Hasyim Asy'ari : Etika dalam Pendidikan Islam. Jurnal Studi Islam, 6(2), 153168.

Baraja, A., Ridlo, A. A., Ali, N., \& Khamid, A. (2020). Konsep Etika Pelajar (Studi Komparasi Kh. Hasyim Asy'ari dan Umar bin Ahmad Baraja). Jurnal Pendidikan Islam Al-Affan, 1(1), 1-13.

Djunaidi A.Syukur dkk, Pondok Pesantren Al-Munawwir .Krapyak Yogyakarta: EL Muna “Q” Pondok pesantren Al-Munawwir,1998.

Hidayah, U. (2018). Rekontruksi Evaluasi Pendidikan Moral Menuju Harmoni Sosial. Jurnal Pedagogik, 05(01), 69-81.

Ikhsanuddin, M., \& Amrulloh, A. (2019). Etika Guru dan Murid Perspektif KH. Hasyim Asy'ari dan Undang- Undang Guru dan Dosen. Jurnal Pendidikan Islam, 3(2), 193-194.

Khosiah, N. (2019). Pelaksanaan Pendidikan Karakter Di MI Miftahul Ulum TambakRejo

Tongas Probolinggo. Ar-Risalah: Media Keislaman, Pendidikan Dan Hukum Islam, 17(1),

118-128.

Martono. (2020). Pemikiran Pendidikan Islam KH . Hasyim Asy' ari ( Perspektif Epistimologi Sosial Keagamaan Dan Konsep Pendidikan Islam Bagi Guru Dan Peserta Didik ). Jurnal Pendidikan Islam, 6(1), 40-45.

Humanistika: Vol.8 No.1 2022 


\section{Konsep Etika Pelajar Terhadap Guru}

(Studi Komparasi Pemikiran K.H. Hasyim Asy'ari dan K.H. Zainal Abidin Munawir)

Muhammad, D. H., \& Deasari, A. E. K. A. (2021). Pendidikan Anak Usia Dini Berbasis Psikologi Islam. Jurnal Pendidikan Islam Al- Ilmi, 4(1), 21-33.

Nata, Abuddin. Perspektif Islam tentang Pola Hubungan Guru-Murid: Studi Pemikiran Tasawuf Al-Ghazali. Jakarta: PT RajaGrafindo Persada. 2001.

Prasetiya, B. (2018). Dialektika Pendidikan Akhlak dalam Pandangan Ibnu Miskawaih dan Al-Gazālī. Intiqad: Jurnal Agama Dan Pendidikan Islam, 10(2), 249-267.

Sugiarto, A. B. (2019). Adab Peserta Didik Terhadap Pendidik Prespektif KH. Zainal Abidin Munawwir dan Relevansinya Dengan Pendidikan Islam (Tela `ah Kitab Wazhaif al-Muta’allim).

Susandi, A. (2020). Pendidikan Life Skills Dalam Penanaman Nilai-Nilai Agama Islam Di Sekolah Dasar. Al-Insyiroh: Jurnal Studi Keislaman, 6(2), 95-111. https://doi.org/10.35309/alinsyiroh.v6i2.3867

Zainal Abidin Munawwir, Wazhaif Al-Muta'allim. Yogyakarta : Pondok Pesantren Al Munawwir, 1964.

Zed. M (2018), Metode penelitian kepustakaan. Jakarta : Yayasan Obor. 